\title{
Small Diameter Hysteroscopy: Is it a Real Opportunity?
}

\author{
Enrico Michelino Messalli*, Flavio Grauso, Domenico Labriola and Pasquale De Franciscis, \\ University of Campania "Luigi Vanvitelli", Italy
}

Submission: March 07, 2017 ; Published: March 20, 2017

*Corresponding author: Enrico M Messalli, University of Campania “Luigi Vanvitelli”, Largo Madonna delle Grazie, 80138 Napoli, Italy, Tel: +390815665601; Email: enricom.messalli@unicampania.it

\begin{abstract}
The hysteroscopy is the gold standard for treatment of uterine intracavitary diseases. It is effective and safe with low rate of recurrence and complications. The features of intrauterine lesions are factors influencing the instrument choice. The larger are generally treated by resectoscope but this technique is associated with potential serious complications mainly due to the need of cervical dilatation. To overcome this limitation, technological improvements have led to the introduction of small-diameter hysteroscopes not exceeding $5 \mathrm{~mm}$ in diameter equipped with bipolar electrodes that work in saline solution. The vaginoscopic approach avoids the use of speculum and tenaculum, and the small caliber of the instruments avoids cervical dilatation; therefore small-diameter hysteroscopes are more suitable. However, the major challenge in the use of small diameter hysteroscopy is the extraction of tissue fragments through a narrow cervical canal. Therefore, hysteroscopic morcellation is introduced.It provides a fast, effective and safe alternative to bipolar resectoscopy in the hysteroscopic treatment of endometrial polyps, but future trials are required for assess cost-effectiveness and cost-benefit ratio. To date, there are no guidelines defining the limits of the size, location and number beyond which small diameter hysteroscopy should be preferred to the resectoscopy. However, the indications for smalldiameter operative hysteroscopy are expanding and not yet completely defined; in experienced hands a small-diameter hysteroscopy is a safe and effective approach for benign endometrial disease up to $4 \mathrm{~cm}$, especially in patients with unfavourable cervical canal at risk of cervical injury.

Keywords: diameter; Hysteroscopy; Resectoscope; Hysteroscopic morcellation
\end{abstract}

\section{Introduction}

The hysteroscopic approach is the gold standard for treatment of uterine intracavitary benign diseases because it is effective and safe with low rate of recurrence and complications $[1,2]$.

The size, shape and location of adhesions, septa, polyps and/or myomas are factors influencing the instrument choice. The larger benign lesions are generally treated by resectoscope equipped with monopolar or bipolar knife [3]. When compared to monopolar, bipolar resectoscopy reduces the risk of electrolyte disturbances and burns; for these reasons, it is the preferred method $[4,5]$.

Despite the excellent results, the resectoscopic technique may be associated with serious complications due to the need of cervical dilatation in addition to thermal injuries or fluid intravasation [6,7]. In fact, most of the complications are related to cervical dilatation and not to the specific hysteroscopic procedures, regardless of the surgeons' experience [8].

Nulliparity, postmenopausal state, stenosis of cervical canal, postmenopausal small cervix [9], previous surgery on the cervix and previous cesarean sections are all conditions able to make difficult to dilate the cervical canal increasing the risk of traumatic lesions (cervical trauma, false track, uterine perforation) $[10,11]$.

Other strategies to avoid cervical injury include the use of laminaria japonica and vaginal prostaglandins. However, the evidence is unclear as to whether the dilatory effect of prostaglandins is apparent in a nonpregnant cervix; moreover, any potential benefit must to be weighed against unpleasant adverse effects (nausea, vomiting and excessive bleeding) and the costs associated with prostaglandin use [10]. Currently, there is insufficient evidence to recommend their routine use preoperatively in outpatient hysteroscopy. Cervical priming with vaginal prostaglandins may be considered in selected postmenopausal women if using hysteroscopic systems $>5 \mathrm{~mm}$ in diameter $[10,12]$.

\section{Discussion}

Technological improvements have led to the introduction of small-diameter hysteroscopes not exceeding $5 \mathrm{~mm}$ in diameter 
equipped with bipolar electrodes that work in saline solution. They allow a simple and safe treatment of many intrauterine diseases, reducing the risk of severe complications $[13,14]$. In fact, the vaginoscopic approach avoids the use of speculum and tenaculum, and the small caliber of the instruments avoids cervical dilatation; therefore small-diameter hysteroscopes are more suitable for patients with "unfavorable" cervix [11].

The small diameter hysteroscopy can play a key role in the diagnosis and treatment of relatively common lesion of low genital tract in children and adolescents [15]. The vaginal examination of these patients necessitates the use of a pediatric speculum, an instrument that is relatively traumatic and can cause erosions or lacerations to the hymen and vaginal walls [16]. The difficulty in performing a gynaecological examination in a child (even under anaesthesia) may delay diagnosis and treatment. The evaluation of the lower genital tract using a small diameter hysteroscope is, therefore, an ideal option by enabling good inspection of the vaginal walls and cervix without trauma to the genital structures [15].

The employment of mini hysteroscopes and vaginoscopic approach has been developed to improve feasibility and reduce pain and side effects allowing a wide spread of the outpatient hysteroscopy. The reduction in the size of the instrument is of great importance for reducing pain and risk of vasovagal reactions [17]. Several studies confirmed that pain and vasovagal reactions were significantly lower with the minihysteroscope compared with the standard [18-20].

However, the major challenge in the use of small diameter hysteroscopy is the extraction of tissue fragments through a narrow cervical canal. To overcome this limitation preserving the small diameter of instrument in 2005 an alternative to resectoscopyis marketed: hysteroscopic morcellation [21]. This mechanical technique combines cutting and aspiration, using saline as continuous flow irrigation solution. Possible benefits in comparison with bipolar resectoscopy are: reduction of operative time; mechanically cut of tissue without lateral electrical damage; no gas bubbles arising upon activation of the device, resulting in better vision and reduced risk of complications such as gas embolism [22]; continuous aspiration of the tissue fragments by hysteroscopic morcellation ensuring a clear view and an immediately collection of tissue for histological examination [3]. However, there are also disadvantages, such us the inability to coagulate bleeding vessels [23] or the cost of the disposables (blades, tubings) needed to perform hysteroscopic morcellation, that is higher compared with the reusable instruments for resectoscopy [3].

Hysteroscopic morcellation may, however, diminish the risk of (re)introduction related perforation, as a result of immediate tissue removal, with less hysteroscope reinsertions [3].

Hysteroscopic morcellation provides a fast, effective and safe alternative to bipolar resectoscopy in the hysteroscopic treatment of endometrial polyps, but future trials are required for other types of intrauterine pathology, as well as comparison of different hysteroscopic morcellation techniques. Possible benefits about training, clinical impact and cost-effectiveness need to be further assessed [3].

To date, there are no guidelines defining the limits of the size, location and number beyond which small diameter hysteroscopy should be preferred to the resectoscopy. However, there is generally agreed that resectoscopic treatment of endometrial polyps should be reserved to patients who are reluctant to tolerate an ambulatory operative procedure, or where the size and/or number of polyps or myomas, and/or type of lesions would require an extensive exploratory procedure [1]. Therefore, endometrial polyps and submucosal myomas less than $2 \mathrm{~cm}$ in diameter are treated with small-diameter hysteroscopes, while larger or multiple endometrial pathologies require the resectoscope $[24,25]$.

The most of available studies compare small diameter hysteroscopy and resectoscopy in patients undergoing anaesthesia. However, the combination of a new generation small diameter hysteroscope and a new bipolar electrode enables the gynaecologist to treat intrauterine pathologies in an office setting without anaesthesia [24]. This is an additional benefit in patients who cannot tolerate general or spinal anaesthesia.

\section{Conclusion}

According to our opinion the indications for small-diameter operative hysteroscopy are expanding and not yet completely defined; in experienced hands a small-diameter hysteroscopy is a safe and effective approach for benign endometrial disease up to $4 \mathrm{~cm}$, especially in patients with unfavourable cervical canal at risk of cervical injury. Hysteroscopic morcellation is an enhanced alternative to the small diameter hysteroscopy even if with higher costs.

\section{References}

1. Di Spiezio Sardo A, Calagna G, Guida M, Perino A, Nappi C (2015) Hysteroscopy and treatment of uterine polyps. Best Pract Res Clin Obstet Gynaecol 29(7): 908-919.

2. Preutthipan S, Herabutya Y (2005) Hysteroscopic polypectomy in 240 premenopausal and postmenopausal women. Fertil Steril 83(3): 705709.

3. Hamerlynck TW, Schoot BC, van Vliet HA, Weyers S (2015) Removal of Endometrial Polyps: Hysteroscopic Morcellation versus Bipolar Resectoscopy, A Randomized Trial. Journal of Minimally Invasive Gynecology 22(7): 1237-1243.

4. Bahar R, Shimonovitz M, Benshushan A, Shushan A (2013) Case-Control Study of 390 complications associated with bipolar and monopolar hysteroscopic operations. J Minim Invasive Gynecol 20: 376-380.

5. De Franciscis P, Grauso F, Cobellis L, Messalli EM, Cucinella G, et al. (2016) Outcomes of monopolar versus bipolar endometrial ablation on uterine bleeding and psychophysical wellbeing. Minerva Ginecol.

6. Indman PD, Brooks PG, Cooper JM, Loffer FD, Valle RF, et al. (1998) Complications of fluid overload from resectoscopic surgery. J Am Assoc Gynecol Laparosc 5: 63-67. 
7. Overton C, Hargreaves J, Maresh M (1997) A national survey of the complications of endometrial destruction for menstrual disorders: the MISTLETOE study. Minimally Invasive Surgical Techniques--Laser, EndoT hermal or Endorescetion. Br J Obstet Gynaecol 104(12): 13511359.

8. Shveiky D, Rojansky N, Revel A, Benshushan A, Laufer N, et al. (2007) Complications of hysteroscopic surgery: "Beyond the learning curve". ] Minim Invasive Gynecol 14(2): 218-222.

9. Greendale GA, Zibecchi L, Peterson L, Ouslander JG, Kahn B, et al. (1999) Development and validation of a physical examination scale to assess vaginal atrophy and inflammation. Climateric 2(3): 197-204.

10. Cooper NA, Smith P, Khan KS, Clark TJ (2011) Does cervical preparation before outpatient hysteroscopy reduce women's pain experience? A systematic review. BJOG 118(11): 1292-1301.

11. De Franciscis P, Grauso F, Messalli EM, Schettino MT, Calagna G, et al. (2016) Resectoscope versus small diameter hysteroscopy for endometrial polypectomy in patients with "unfavorable" cervix. Minerva Ginecol.

12. Selk A, Kroft J (2011) Misoprostol in operative hysteroscopy: a systematic review and meta-analysis. Obstet Gynecol 118(4): 941-949.

13. Marwah V, Bhandari SK (2003) Diagnostic and interventional microhysteroscopy with use of the coaxial bipolar electrode system. Fertil Steril 79(2): 413-417.

14. Colacurci N, De Franciscis P, Mollo A, Litta P, Perino A, et al. (2007) Small-diameter hysteroscopy with Versapoint versus resectoscopy with a unipolar knife for the treatment of septate uterus: a prospective randomized study. J Minim Invasive Gynecol 14(5): 622-627.

15. Smorgick N, Padua A, Lotan G, Halperin R, Pansky M (2009) Diagnosis and treatment of pediatric vaginal and genital tract abnormalities by small diameter hysteroscope. J Pediatr Surg 44(8): 1506-1508.

16. Pokorny SF (1993) The genital examination of the infant through adolescence. Curr Opin Obstet Gynecol 5(6): 753-757.
17. Cicinelli E (2005) Diagnostic mini hysteroscopy with vaginoscopic approach: rationale and advantages. J Minim Invasive Gynecol 12(5): 396-400.

18. Cicinelli E, Schonauer LM, Barba B, Tartagni M, Luisi D, et al. (2003) Tolerability and cardiovascular complications of outpatient mini hysteroscopy compared with conventional hysteroscopy. J Am Assoc Gynecol Laparosc 10(3): 399-402.

19. Rullo S, Sorrenti G, Marziali M, Ermini B, Sesti F, et al. (2005) Office hysteroscopy: comparison of $2.7-$ and 4-mm hysteroscopes for acceptability, feasibility and diagnostic accuracy. J Reprod Med 50: 4548.

20. Campo R, Molinas CR, Rombauts L, (2005) Prospective multicentre randomized controlled trial to evaluate factors influencing the success rate of office diagnostic hysteroscopy. Hum Reprod 20(1): 258-263.

21. Emanuel MH, Wamsteker K (2005) The intra uterine morcellator: a new hysteroscopic 393 operating technique to remove intrauterine polyps and myomas. J Minim Invasive Gynecol 12: 62-66.

22. Murakami T, Tamura M, Ozawa Y, Suzuki H, Terada Y, et al. (2005) Safe 396 techniques in surgery for hysteroscopic myomectomy. J Obstet Gynaecol Res 31: 216-223.

23. Haber K, Hawkins E, Levie M, Chudnoff S (2015) Hysteroscopic morcellation: review of the manufacturer and user facility device experience (MAUDE) database. J Minim Invasive Gynecol 22(1): 110114.

24. Bettocchi S, Ceci O, Di Venere R, Pansini MV, Pellegrino A, et al. (2002) Advanced operative office hysteroscopy without anaesthesia: analysis of 501 cases treated with a 5 Fr. bipolar electrode. Human Reprod 17(9): 2435-2438.

25. Gambadauro P, Martínez-Maestre MA, Torrejón R (2014) When is seeand-treat hysteroscopic polypectomy successful? Eur J Obstet Gynecol Reprod Biol 178: 70-73.

\section{Your next submission with Juniper Publishers} will reach you the below assets

- Quality Editorial service

- Swift Peer Review

- Reprints availability

- E-prints Service

- Manuscript Podcast for convenient understanding

- Global attainment for your research

- Manuscript accessibility in different formats

( Pdf, E-pub, Full Text, Audio)

- Unceasing customer service

Track the below URL for one-step submission https://juniperpublishers.com/online-submission.php 